\title{
Effect of Competence, Organizational Culture, and Motivation towards Employee Performance at PT Kukuh Tangguh Sandang Mills
}

\author{
Yayan Sudaryana \\ Post Graduate Programs, Universitas Pamulang, Tangerang - Banten \\ Email: dosen00497@unpam.ac.id
}

\begin{tabular}{|l|}
\hline How to cite (in APA style): \\
\hline $\begin{array}{l}\text { Sudaryana, Yayan. (2021). Effect of Competence, Organizational Culture, and Motivation towards Employee } \\
\text { Performance at PT Kukuh Tangguh Sandang Mills. Jurnal Ekonomi dan Bisnis Jagaditha, Vol. } 8 \\
\text { (1), 23-29 doi: https://10.22225/ii.8.1.2687.23-29 }\end{array}$ \\
\hline
\end{tabular}

\begin{abstract}
Human resources are an element that will determine the achievement of goals effectively and efficiently. Employee performance is one of the main factors that can affect the progress of an organization or company. This study is intended to identify the extent of competence, organizational culture, and motivation that impress the employee performance at PT Kukuh Tangguh Sandang Mills in Bandung. This kind of causality research underlies in providing explanations and measuring the causal effect and quantitative research approach. Determining the number of samples using the Slovin' calculation formula with a precision of 10 percent to obtain a sample of 76 respondents. Data analysis techniques in this study using the aid of the SPSS for Windows Program. According to the results and discussion on the influence of competence, organizational culture, and motivation on employee performance, it can be concluded that the three determinants simultaneously and partially have a significant positive effect on employee performance. The value of the coefficient of determination was 49.3 percent, which gave a high contribution, namely competence, organizational culture, and motivation to employee performance at PT. Kukuh Tangguh Sandang Mills, Bandung.
\end{abstract}

Keywords: Competence, Organizational Culture, Motivation, Performance

\section{INTRODUCTION}

In an organization, human resources are an element that will determine the achievement of goals effectively and efficiently. Each member of the organization's behavior in carrying out various tasks is a reflection of employee performance. Basically, every member of the organization will devote all his abilities, efforts, and thoughts to improve performance (Pedraza, 2014).

Employee performance is one of the main factors that can affect the progress of an organization or company. The higher or, the better the employee's performance, the easier the organization's goals or company will be achieved, and vice versa. If the employee's performance is low or not good, the goal will be difficult to achieve, and the results received will not be following the company's wishes (Akbar, 2018). Therefore, efforts to improve employee performance are the most serious challenges for management because success in achieving the company's goals and survival depends on the work of the employees in the company.

Performance, according to Siswanto, is an achievement achieved by a person in carrying out the duties and jobs assigned to him (Martha, 2015). Furthermore, Mangkunegara (2013) stated that the implementation of an employee's duties in achieving work results both in quantity and quality based on the responsibilities assigned to him (Sudaryana, 2020). Several important determinants influence employee performances i.e. First, competence is employees' capacity, which leads to behavior based on the demands of the job and according to organizational regulations, which will bring the desired results (Boyatzis, 1982; Vathanophas \& Thaingam, 2007). Second, organizational culture will increase employees' solidarity and familiarity between departments, divisions, or units to create a comfortable and pleasant atmosphere in an organization to achieve the desired performance (Robbins \& Coulter, 2016). 
Third, employees can carry out their duties optimally, among others, determined by the motivation that encourages the employee to work diligently, so that the company's goals can be achieved based on Herzberg (Slamet, 2007).

PT Kukuh Tangguh Sandang Mills hereinafter referred to as "the enterprise," is very committed to managing human resources as long as the organization stands. The enterprise is domiciled in Bandung, supplying raw materials to brands in Europe and America and produces cotton and polyester, operated through spinning, weaving, and finishing departments (Zulfiqar, 2010). According the Pearce \& Robinson Jr (2016), by involving many workers, organizational culture in the context of human resource will certainly be held jointly by members of the organization so that they can sustain and become the basis, direction, and action (Ningrum, 2017).

Enterprise in responding to the era of the industrial revolution 4.0 in facing competitors, especially domestic competitors, of course, need to mobilize the competence of all human resources to develop and, of course, innovate. Enterprises that have designed web-based sales and ordering information systems in this decade can certainly use cloud computing to manage document and file access to structured storage media, synchronize and share data, and reduce data redundancy, which also has its own advantages (Febriana, 2018; Husain \& Budiyantara, 2020). Dessler (2015) states that competency is as a person's characteristic impressing directly to the performance or can prophesy the performance very well so it can bring out an achievement (Sarmawa, Suryani \& Riana, 2015). The role of human resource competence through improved performance is a significant response to expanding the marketing reach of goods throughout Indonesia and globally.

Increased motivation makes work completed faster due to the negative impact of attendance problems will cause morale to decrease, and this can be overcome by increasing work morale, which is also expected to increase employee productivity (Sudiana, 2018). This study is intended to identify the extent of competence, organizational culture, and motivation that impress the employee performance at PT Kukuh Tangguh Sandang Mills in Bandung.

\section{CONCEPT AND HYPOTHESIS}

Performance is the result of work achieved by a person based on job requirements (Bangun, 2012). Furthermore, performance is the result or level of success of a person as a whole during a certain period in carrying out a task compared to various possibilities, such as work standards, targets or targets or criteria that have been predetermined and mutually agreed (Rivai, 2015). The indicator that is used as a measure in assessing performance are: (1) Quantity is the amount produced, expressed in terms such as the number of units, the number of activity cycles completed by the employee, and the number of activities generated; (2) Quality of work is measured by employees' perceptions of the quality of work produced and the perfection of tasks on employee skills and abilities; (3) Timeliness is measured from employee perceptions of an activity completed at the beginning of time until it becomes output; (4) The presence of employees in the company whether they come to work, come home from work, permit, or without information, which entirely affects the employee's performance; and (5) The ability to cooperate is the aptitude of a person in the workforce to cooperate with others in completing a predetermined task and job to achieve maximum effectiveness and efficiency (Mathis \& Jackson, 2012).

Organizational culture is a set of values, principles, traditions, and ways of working that are shared by and influence the behavior and actions of organizational members (Robbins \& Coulter, 2016). In most organizations, these shared values and practices have developed rapidly with the times and have profoundly influenced how an organization is run. The indicator that is used as a measure in assessing organizational culture are: (1) Innovation and risk-taking, namely the degree to which employees are encouraged to be innovative in taking risks; (2) Attention to detail, namely the degree to which employees are expected to be able to demonstrate accuracy, analysis, and attention in detail; (3) results in orientation, namely the leadership focuses on the extent to which the results or output are not on how to achieve those results; (4) People orientation, that is, management decisions also influence the extent to which they have an impact on people in the organization; (5) Team orientation, namely the work arranged based on a team and not on an 
individual basis; (6) Aggressiveness, namely the degree to which employees are aggressive and competitive, rather than cooperative; and (7) Stability or stability, namely the level of decisions and actions of the organization emphasizing the extent to which efforts to maintain the status quo (Nagel, 2006).

According to Dessler (2015), competency usually refers to a function or activity carried out by a manager, such as employee development, where competence is an individual quality that employees bring to work, such as creativity and skills that produce networks. Spencer \& Spencer (1993) states that competence is formed from five characteristics, i.e. motives, traits, selfconcept, knowledge, and skills (Priansa, 2018). The indicator that is used as a measure in assessing competence are: (1) Self characteristics are employees' mental characteristics and consistency of responses to stimuli, pressure, situations, and information. These characteristics determine the emotional level of employees in responding to stimuli and information; (2) Self concept is an employee's description of attitudes, values, and self-image regarding the job, task, or position they face so that they can be realized through their work and business; Knowledge is an employee's ability which is formed from the information they receive; (3) The knowledge possessed by a person predicts what they can do, and even what they will do; and (4) Skill is the employee's ability to perform physical or mental tasks. Competence of knowledge and skills tends to be visible because it is, on the surface, relatively easy to develop, for example, through training or experience. Simultaneously, the competence of self-concept, character, and motives is more hidden in nature and more difficult to develop.

Motivation is the process by which one's efforts are energized, directed, and sustainable towards achieving a goal (Robbins \& Coulter, 2016). Furthermore, work motivation comes from work enthusiasm and the mobility of a person to work together, work effectively, and be integrated with all his efforts to achieve satisfaction (Hasibuan, 2017). The purpose of providing motivation, among others, is to increase: (1) Morale and job satisfaction of employees; (2) Employee productivity; (3) The stability of company employees; (4) Employee discipline; (5) Effectiveness of employee procurement; (6) Good working atmosphere and relationship; (7) Employee loyalty, creativity and participation; (8) Employee welfare level; (9) Employees' sense of responsibility for their duties; and (10) Efficient use of tools and raw materials. The indicator that is used as a measure in assessing motivation accoording to Herzberg are: (1) Relationships with colleagues and superiors through a harmonious atmosphere between employees are established at the workplace, and there is always cooperation between subordinates and superiors and colleagues; (2) Work environment with adequate work support facilities following the needs and working atmosphere as expected; (3) The opportunity to improve the knowledge and skills of a company or organization always provides education and training for its employees; and (4) Providing appropriate allowances for employees by companies or organizations (Slamet, 2007).

Several previous research findings state that: (1) Employees can work well if they can produce good work through the level of education, competence, and compensation, which provide significant results either simultaneously or partially for 68 employees at PT. Jasaraharja Putera Manado Insurance (Mufidah, Mandey \& Mananeke, 2014). (2) Study of the role of teacher commitment and competence as predictors of Organizational Citizenship Behavior (OCB) and its effect on teacher performance in several private vocational high schools in Klungkung Regency, Bali, Indonesia. The results of the study found that OCB commitment had no significant effect on the teacher's performance. Competency factors affect teacher performance (Sarmawa, Suryani \& Riana, 2015). (3) Organizational culture is a set of values that are recognized and embraced by all parties in PT. Standing Sandang Mills on employee performance with the result that the dimensions of organizational culture that are still not fully experience significance that cannot be said to be perfect (Ningrum, 2017). (4) The importance of high work motivation in 30 employees of PT. Bank Central Asia, Tbk, Branch of Kerawang with dimensions of physical needs, need for security and safety, social needs, need for appreciation, need for self-actualization can prove a positive influence on employee performance (Mahpudin \& Purnamasari, 2018). (5) Providing motivation is another important factor in improving employee performance. Giving motivation by an 
organization is an obligation and a demand. Providing good and sustainable motivation in the form of directions or rewards to employees can stimulate employees to work better to achieve the organizational goals that have been previously set (Akbar, 2018). (6) Despite the decline in production results in 2016-2018 by PT ALENATEX, the movement of good employee performance was caused by organizational culture factors through the dimensions of discipline, accuracy, friendliness, responsiveness, and coordination. The research findings produce a positive influence on organizational culture on employee performance (Lionel \& Wardhana, 2019). (7) Service gaps often occur between providers and customers at PT Benesse Indonesia, involving 107 employees. The results of this study indicate that compensation and career development have a positive effect on employee performance (Sudaryana, 2020).

To reply to the proposed research analysis, described in a model. The model represents the support of simple decision-making or a depiction of the reality of an object or activity's phenomena (Sari, 2018; Zailani, Husain, \& Budiyantara, 2020).

Image 1

Research Model

(Sumber: Develop by this study, 2020)

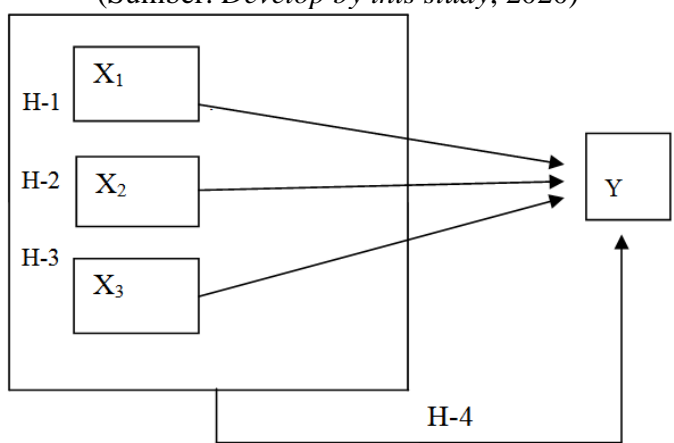

Hypothesis development in this study model as follows:

- $\mathrm{H}_{1}, \mathrm{H}_{2}, \mathrm{H}_{3}$ each of the Competencies, Organizational Culture, and Motivation has a positive and significant consequent towards Employee Performance at PT. Kukuh Tangguh Sandang Mills, Bandung.

- $\mathrm{H}_{4}$ equally on Competence, Organizational Culture, and Motivation have a significant consequent towards Employee Performance at PT. Kukuh Tangguh Sandang Mills, Bandung.

\section{METHOD}

This kind of causality research underlies in providing explanations and measuring the causal effect relationship between variables as a basis for analyzing some of these variables (Supranto \& Limakrisna, 2019). This study uses a quantitative approach with populations are permanent non-structural employees who work at PT. Kukuh Tangguh Sandang Mills Bandung as many as 310 employees. Determining the number of samples in this study using the Slovin calculation formula with a precision of 10 percent to obtain a sample of 76 respondents.

Data analysis techniques in this study using the aid of the SPSS for Windows Program. The validity test uses a product-moment formulation. The reliability test uses the Cronbach Alpha Coefficient formulation. The Classical Assumption Test, i.e., the Normality Test, Multicollinearity test, Heteroscedasticity test. Regression analysis using simple linear regression $\mathrm{Y}=\mathrm{a}+\mathrm{bX}$ and multiple linear regression $\mathrm{Y}=\mathrm{a}+\mathrm{b} 1 \mathrm{X} 1+\mathrm{b} 2 \mathrm{X} 2+\ldots . . \mathrm{bnXn}$; Analysis of the coefficient of determination with the value of R Square; and Hypothesis Testing with the provisions that Ho is rejected and $\mathrm{Ha}$ is accepted if $\mathrm{t}$ value $>\mathrm{t}$ table and $\mathrm{F}$ stats $>\mathrm{F}$ table.

\section{RESULT AND DISCUSSION}

1. The Determination of Coefficients Summary of Competence, Organizational Culture, and Motivation in Employee Performance

Table 1.

Partial Output: Summary of Determination Coefficients

\begin{tabular}{lllcc}
\multicolumn{1}{c}{ Model } & $\mathbf{R}$ & $\mathbf{R}^{2}$ & Adj. $\mathbf{R}^{2}$ & $\begin{array}{c}\text { Std. Error } \\
\text { of Estimate }\end{array}$ \\
\hline $\begin{array}{l}\text { Competence } \\
\text { (X1) }\end{array}$ & 0.546 & 0.298 & 0.289 & 2.654 \\
\hline $\begin{array}{l}\text { Organizatio- } \\
\text { nal Culture } \\
\text { (X2) }\end{array}$ & 0.573 & 0.329 & 0.320 & 2.596 \\
\hline $\begin{array}{l}\text { Motivation } \\
\text { (X2) }\end{array}$ & 0.576 & 0.331 & 0.322 & 2.591 \\
\hline & & \multicolumn{3}{c}{ (Calculated from SPSS, 2020) }
\end{tabular}

Based on the calculation of the coefficient of determination, each of $0.298,0.329$, and 0.331, the magnitude of the contribution of impact competence, organizational culture, and motivation on employee performance at PT. Kukuh Tangguh Sandang Mills Bandung by 29.8 percent, 32.9 percent, and 33.1 percent. Hereinafter, each salvage score is (1 minus R- 
Square result), which is influenced by other factors not included in this research model.

\section{The Impression of each of Competence, Organizational Culture, and Motivation in Employee Performance}

Table 2.

Partial Output: Competence

\begin{tabular}{lcccc}
\multicolumn{1}{c}{ Model } & $\boldsymbol{\beta}$ & $\begin{array}{c}\text { Std } \\
\text { Error }\end{array}$ & t-value & $\begin{array}{c}\text { Sig. } \\
\text { Probability }\end{array}$ \\
\hline Constant & 19.514 & 4.181 & 4.667 & 0.000 \\
\hline $\begin{array}{l}\text { Competence } \\
\text { (X1) }\end{array}$ & 0.548 & 0.098 & 5.606 & 0.000 \\
\hline
\end{tabular}

Based on the calculation of the t-value (5.606) is greater than the t-table score (1.993), and the score of sig. probability $(0.000)$ is less than alpha (0.05), it means a positive and significant impression of competence on employee performance at PT. Kukuh Tangguh Sandang Mills in Bandung. The linear regression equation $\mathrm{Y}=19.514+0.548 \mathrm{X} 1$ means that if the competency increases by one squad, the performance will increase by 0.548 .

Table 3.

Partial Output: Organizational Culture

\begin{tabular}{lcccc}
\hline \multicolumn{1}{c}{ Model } & $\boldsymbol{\beta}$ & $\begin{array}{c}\text { Std } \\
\text { Error }\end{array}$ & t-value & $\begin{array}{c}\text { Sig. } \\
\text { Probability }\end{array}$ \\
\hline Constant & 19.007 & 3.978 & 4.778 & 0.000 \\
\hline $\begin{array}{l}\text { Organizatio- } \\
\text { nal Culture } \\
\text { (X2) }\end{array}$ & 0.544 & 0.090 & 6.021 & 0.000 \\
\hline
\end{tabular}

(Calculated from SPSS, 2020)

Based on the calculation of the t-value (6.021) is greater than the t-table score (1.993), and the score of sig. probability $(0.000)$ is less than alpha (0.05), it means a positive and significant impression of organizational culture on employee performance at PT. Kukuh Tangguh Sandang Mills in Bandung. The linear regression equation $\mathrm{Y}=19.007+0.544 \mathrm{X} 2$ means that if the organizational culture increases by one squad, the performance will increase by 0.544 .

Table 4

Partial Output: Motivation

\begin{tabular}{lcccc}
\hline \multicolumn{1}{c}{ Model } & $\boldsymbol{\beta}$ & $\begin{array}{c}\text { Std } \\
\text { Error }\end{array}$ & t-value & $\begin{array}{c}\text { Sig. } \\
\text { Probability }\end{array}$ \\
\hline Constant & 22.330 & 3.408 & 6.553 & 0.000 \\
\hline $\begin{array}{l}\text { Motivation } \\
\text { (X3) }\end{array}$ & 0.473 & 0.078 & 6.058 & 0.000 \\
\hline
\end{tabular}

(Calculated from SPSS, 2020)

Based on the calculation of the t-value (6.058) is greater than the t-table score (1.993), and the score of sig. probability (0.000) is less than alpha (0.05), it means a positive and significant impression of motivation on employee performance at PT. Kukuh Tangguh Sandang Mills in Bandung. The linear regression equation $\mathrm{Y}=22.330+0.0473 \mathrm{X} 3$ means that if the motivatio increases by one squad, the performance will increase by 0.473 .

\section{The Model Influence of Simultaneously and Partially of Competence, Organizational Culture, and Motivation in Employee Performance at PT. Kukuh Tangguh Sandang Mills in Bandung}

Table 5.

Model Output: Summary of Determination Coefficients

\begin{tabular}{lllcc}
\hline Model & $\mathbf{R}$ & $\mathbf{R}^{2}$ & Adj. $\mathbf{R}^{2}$ & $\begin{array}{c}\text { Std. Error } \\
\text { of Estimate }\end{array}$ \\
\hline 1 & 0.717 & 0.514 & 0.493 & 2.240 \\
\hline \multicolumn{4}{c}{ (Calculated from SPSS, 2020) }
\end{tabular}

Based on the calculation of the coefficient of determination, 0.493 (adj.), the magnitude of the high contribution of impact competence, organizational culture, and motivation on employee performance at PT. Kukuh Tangguh Sandang Mills Bandung by 49.3 percent and no influenced by other factors not included in this research model is 50.7 percent.

Table 6.

Model Simultan Output: Competence, Organizational Culture, and Motivation in Employee Performance

\begin{tabular}{lrrrc}
\hline Model & df & Mean Square & F-Stats & $\begin{array}{c}\text { Sig. } \\
\text { Probability }\end{array}$ \\
\hline 1 & 3 & 127.249 & 25.350 & 0.000 \\
\hline \multicolumn{5}{r}{} \\
\hline
\end{tabular}

(Calculated from SPSS, 2020)

Based on the calculation of the F-stats (25.350) is greater than the F-table score (3.11), and the score of sig. probability (0.000) is less than alpha (0.05), thus Reject $\mathrm{H}_{0}$ and Accept $\mathrm{H}_{\mathrm{a}}$ means a positive and significant impression of competence, organizational culture, and motivation towards employee performance at PT. Kukuh Tangguh Sandang Mills in Bandung.

Table 7.

Model Partial Output: Competence, Organizational Culture, and Motivation in Employee Performance

\begin{tabular}{llccc}
\hline \multicolumn{1}{c}{ Model } & $\boldsymbol{\beta}$ & $\begin{array}{c}\text { Std } \\
\text { Error }\end{array}$ & t-value & $\begin{array}{c}\text { Sig. } \\
\text { Probability }\end{array}$ \\
\hline Constant & 6.853 & 4.234 & 1.555 & 0.124 \\
\hline $\begin{array}{l}\text { Competence } \\
\text { (X1) }\end{array}$ & 0.286 & 0.095 & 3.027 & 0.003 \\
\hline Organizatio- & 0.295 & 0.091 & 3.229 & 0.002 \\
\hline
\end{tabular}


Effect of Competence, Organizational Culture, and Motivation towards Employee Performance at PT Kukuh Tangguh Sandang Mills

\begin{tabular}{lllll}
\hline \hline \hline $\begin{array}{l}\text { nal Culture } \\
\text { (X2) }\end{array}$ & & & & \\
\hline $\begin{array}{l}\text { Motivation } \\
\text { (X3) }\end{array}$ & 0.256 & 0.079 & 3.226 & 0.002 \\
\hline & & & & \\
\hline
\end{tabular}

From the partial analysis (from table 7), the tvalue (3.027) is greater than the score of the ttable hypothesis, which states that there is a positive and significant impress on competence towards employee performance accepted $\left(\mathrm{H}_{1}\right)$. This study's results align with the positive findings on competence in employee performance (Mufidah, Mandey \& Mananeke, 2014; Sarmawa, Suryani \& Riana, 2015). Then, the partial analysis (from table 7), the t-value (3.229) is greater than the score of the t-table hypothesis, which states that there is a positive and significant impress on organizational culture towards employee performance accepted $\left(\mathrm{H}_{2}\right)$. This study's results align with the positive findings on organizational culture in employee performance (Lionel \& Wardhana, 2019; Ningrum, 2017), while contradicting that organizational culture does not improve teacher performance through OCB (Sarmawa, Suryani \& Riana, 2015). Besides, the partial analysis (from table 7), the t-value (3.226) is greater than the score of the t-table hypothesis, which states that there is a positive and significant impress on motivation towards employee performance accepted $\left(\mathrm{H}_{3}\right)$. This study's results align with the positive findings on motivation in employee performance (Mahpudin \& Purnamasari, 2018).

From the simultaneous analysis (from table 6), the F-stats (25.350) is greater than the F-table hypothesis's score, which states that there is a positive and significant impress on competence, organizational culture, and motivation towards employee performance. Calculation of the coefficient of determination (from table 5), 49.3 percent produces the magnitude of the quite high contribution of impact competence, organizational culture, and motivation on employee performance at PT. Kukuh Tangguh Sandang Mills, Bandung.

\section{CONCLUSION}

According to the results and discussion on the influence of competence, organizational culture, and motivation on employee performance, it can be concluded that the three determinants simultaneously and partially have a significant positive effect on employee

performance. The value of the coefficient of determination was 49.3 percent, which gave a high contribution, namely competence, organizational culture, and motivation to employee performance at PT. Kukuh Tangguh Sandang Mills, Bandung. The suggestion of this study i.e. (1) employee competencies in the enterprise are in a good category. However, related to personal character, management needs to pay more attention to its employees; (2) organizational culture in the enterprise are in a good category. However, for innovation and risk taking as well as the stability or stability of employees at work, it still needs to be further improved; and (3) motivation in the enterprise is in a good category. However, employee attendance should be maintained and still need to be improved, especially in the discipline of work attendance.

\section{REFERENCES}

Akbar, S. (2018). Analisa Faktor-Faktor yang Mempengaruhi Kinerja Karyawan. JIAGANIS (Jurnal Ilmu Administrasi Negara Dan Bisnis), $3(2)$.

Bangun, W. (2012). Manajemen Sumber Daya Manusia. Jakarta: Erlangga.

Boyatzis, R. E. (1982). The competent manager: A model for effective performance. New York: John Wiley \& Sons.

Dessler, G. (2015). Human Resources Management. England: Pearson Education Limited.

Febriana, F. (2018). Perancangan Sistem Informasi Penjualan berbasis Web Di PT. Kukuh Tangguh Sandang Mills (KTSM) Bandung. Bandung: Universitas Komputer Indonesia.

Hasibuan, M. S. (2017). Manajemen Sumber Daya Manusia (18th ed.). Jakarta: PT Bumi Aksara.

Husain, T., \& Budiyantara, A. (2020). Analysis of Control Security and Privacy Based on eLearning Users. SAR Journal, 3(2).

Lionel, A., \& Wardhana, A. (2019). Pengaruh Budaya Organisasi terhadap Kinerja Karyawan di PT ALENATEX. E-Proceeding of Management. Bandung: Prodi Administrasi Bisnis, Fakultas Komunikasi dan Bisnis Universitas Telkom.

Mahpudin, E., \& Purnamasari, P. (2018). Pengaruh Motivasi Kerja terhadap Kinerja Karyawan pada PT Bank Central Asia, Tbk Cabang Karawang. Jurnal Edunomic, 6(2).

Mangkunegara, A. (2013). Manajemen Sumber Daya Manusia dan Perusahaan. Bandung: Penerbit Remaja Rosdakarya.

Martha, M. S. (2015). Karakteristik Pekerjaan dan Kinerja Dosen Luar Biasa UIN Sunan Gunung 
Djati Bandung: Komitmen Organisasi Sebagai Variabel Moderating. Bandung: Universitas Widayatama.

Mathis, R. L., \& Jackson, J. H. (2012). Manajemen Sumber Daya Manusia (Buku 1). (J. Sadeli, \& B. P. Hie, Penerj.). Jakarta: Salemba Empat.

Mufidah, Mandey, S. L., \& Mananeke, L. (2014). Analisis Tingkat Pendidikan, Kompetensi dan Kompensasi terhadap Kinerja Karyawan pada PT Asuransi Jasa Raharja Putera Manado. Jurnal EMBA, 2(4).

Nagel, R. N. (2006). Organizational Behavior an Organizational Change Organizational Culture: CSE \& Enterprise Systems Center. Pennsylvania: Lehigh University.

Ningrum, M. S. (2017). Pengaruh Budaya Organisasi dan Ketidakpastian Lingkungan terhadap Kualitas Sistem Informasi Akuntansi Manajemen (Studi pada PT Kukuh Tangguh Sandang Mills). Jurnal Akuntansi, Audit Dan Sistem Informasi Akuntansi AKUTANSI (JASa), l(2).

Pearce, J. A., \& Robinson Jr, R. B. (2016). Manajemen Strategis (Buku 1) (12th ed.). Jakarta: Salemba Empat.

Pedraza, J. M. (2014). What is organisational effectiveness and how an organization could achieve it?

Priansa, D. J. (2018). Perencanaan \& Pengembangan SDM. Bandung: Alfabeta.

Rivai, V. (2015). Manajemen Sumber Daya Manusia Untuk Perusahaan: Dari Teori ke Praktik (III). Jakarta: PT. Raja Grafindo Persada.

Robbins, S. P., \& Coulter, M. (2016). Manajemen (Jilid 1 dan 2). (B. Sabran, \& W. Hardani, Penerj.) (13th ed.). Jakarta: Erlangga.

Sari, F. (2018). Metode dalam Pengambilan Keputusan (1st ed.). Sleman: Deepublish (CV. Budi Utama).

Sarmawa, I., Suryani, N., \& Riana, I. G. (2015). Commitment and competency as an organizational citizenship behaviour Predictor and its effect on the performance (A Study of Private Vocational High Schools in Klungkung Regency, Bali, Indonesia). International Journal of Economics, Commerce and Management, 3(1).

Slamet. (2007). Kiat Meningkatkan Kinerja (1st ed.). Jakarta: PT. Rineka Cipta.

Spencer, L., \& Spencer, S. M. (1993). Competence at Work, Models for Superior Performance. Canada: John Wiley \& Sons, Inc.

Sudaryana, Y. (2020). Effect Of Compensation And Career Development To The Employee Performance (Study At PT. Benesse Indonesia). Journal of Management Review, 4(2).

Sudiana, D. (2018). Pengaruh Penempatan Jabatan Terhadap Semangat Kerja Pegawai Pada
Organisasi Perangkat Daerah Kabupaten Ciamis. Jurnal DINAMIKI, 5(3).

Supranto, J., \& Limakrisna, N. (2019). Petunjuk Praktis Penelitian Ilmiah untuk Menyusun Skripsi, Tesis dan Disertasi (5th ed.). Bogor: Penerbit Mitra Wacana Media.

Vathanophas, V., \& Thaingam, J. (2007). Competency Requirements for Effective Job Performance in The Thai Public Sector. Contemporary Management Research, 3(1).

Zailani, A. U., Husain, T., \& Budiyantara, A. (2020). Analisis Simulasi Sistem Penunjang Keputusan: Model Matematis Dengan Pendekatan Goodness-of Fit Berbasis Structural Equation Model. SMARTICS Journal, 6(1).

Zulfiqar, A. E. (2010). Perancangan Tata Letak Fasilitas Pabrik di PT. Kukuh Tangguh Sandang Mills dengan Menggunakan Algoritma Craft. Bandung: Institut Teknologi Telkom. 